\title{
Radical practice in a risk-averse environment: Learning from ATD Fourth World UK
}

\author{
Hannah Blumhardt' ${ }^{1}$ ATD Fourth World UK² and Anna Gupta ${ }^{3}$
}

\begin{abstract}
INTRODUCTION: The escalation of coercive, risk-averse policy directives in Aotearoa New Zealand's child and family social work sphere is undermining the profession's potential to meet its social justice, human rights based aspirations. Social workers may need to look further afield for best practice models that facilitate emancipatory practice in neoliberal social policy environments. This article posits the radical practice of anti-poverty organisation ATD Fourth World in England (where child protection is characteristically risk-averse, individualised and coercive), as an alternative for work with families experiencing poverty and social exclusion.

METHODS: We drew on the voices of ATD Fourth World activists cited in previous publications, alongside Activists(a-d) interviewed specifically for this article, and Activist(e) who contributed at a roundtable discussion on a previous project. Interviews focused on ATD Fourth World's approach to working with families in poverty; three distinctive aspects emerged: the organisation's philosophy on poverty, and its collaborative and relational family support model. We contrasted these three aspects with state child protection policies in Aotearoa New Zealand and England.
\end{abstract}

FINDINGS: The often inflexible, top-down nature of state child protection policies, coupled with an atmosphere of policing, control and disregard for the impact of poverty, constrain social workers and families alike, eroding the crucial social worker/family relationship underpinning best practice. ATD Fourth World's approach suggests that genuine strengths-based practice relies on nuanced understandings of poverty, a commitment to advance families' wishes, and trusting relationships grounded in human dignity and commonality.

CONCLUSION: The Aotearoa New Zealand reforms may amplify coercive, risk-averse tendencies in the state's child protection system. Child and family social workers could consider adapting aspects of ATD Fourth World's approach to resist or mitigate these coercive aspects and steer the reforms' implementation in more emancipatory directions.

KEYWORDS: poverty; collaboration; relational practice; risk; reform; families

A cursory inspection of recent social work literature in Aotearoa New Zealand demonstrates rising alarm about the ideology underpinning child protection system reforms. Under the auspices of three successive National-led governments, Aotearoa New Zealand's long-term vision for child welfare has shifted from its hallmark, whānau-led approach towards a risk-averse, individualised blueprint likely to subject disadvantaged families to coercive surveillance and regulation (Hyslop, 2009; Keddell, 2014; Martin, 2016; O'Brien, 2016). Examples include the recommendations of the 2011 Green Paper and the 2012 White Paper for Vulnerable
${ }^{1}$ Independent researcher

${ }^{2}$ Anti-poverty non-governmental organisation https://www.atd-uk.org/

${ }^{3}$ Royal Holloway, University of London, United Kingdom

AOTEAROA NEW ZEALAND SOCIAL WORK 29(2), 19-33.

CORRESPONDENCE TO: Hannah Blumhardt blumhardt.hannah@gmail.com 
Children; the insertion of the paramountcy principle in the Child, Young Persons and their Families Act 1989 (CYPFA); the introduction of the Vulnerable Children Act 2014 (VCA); and the overhaul and replacement of Child, Youth and Family (CYF) with Oranga Tamariki (the Ministry for Vulnerable Children), following the final report and recommendations of the Modernising Child Youth and Family Expert Panel (Expert Panel, 2015). ${ }^{\mathrm{i}}$

The path that New Zealand's reforms are carving is all-too-familiar in England, where the drift towards risk-aversion has undermined the quality of social services provision (Featherstone, Morris, \& White, 2014; Gupta, Blumhardt, \& ATD, 2016; Warner, 2015). Forebodingly, the President of the Family Court Division of the High Court recently warned of a "looming crisis" as the English care system buckles under soaring numbers of children in care (Munby, 2016, n.p.). Illustrating the atmosphere of disillusionment, Featherstone, Morris, and White (2013) observe social workers" increasing "disquiet about contemporary policy and practice, and anxiety that the social justice aspect of social work is being lost in a child protection project ... characterized by a muscular authoritarianism towards multiply deprived families" (p. 19).

This anxiety demonstrates the fragility of the social work profession's aspiration to promote human flourishing and emancipatory social justice (Hyslop, 2009; Keddell, 2011), highlighting the internal tension within the profession's twin directive to provide both care and control. As Hyslop (2009) notes, the "essence of social work is described as a contradictory mix of surveillance and empowerment," which "constantly seeks to balance an uneasy dialectical essence in its positioning at the intersection of social care and social control" (pp. 62-63). In England, risk-averse, neoliberal agendas have tipped child welfare policies overly towards control. Preserving the balance in post-reform Aotearoa New
Zealand requires scrutiny of possible strategies for maintaining social work's humane ethic in increasingly oppressive climates. This article posits anti-poverty organisation, All Together in Dignity Fourth World's (hereafter, ATD) radical socialjustice-based practice-which amplifies transformational goals even in neoliberal contexts-as inspiration, via three themes: acknowledging and addressing the impact of poverty; maximising collaborative practice; and adopting relational approaches to service provision.

ATD is a human rights based, anti-poverty, non-governmental organisation (NGO) operating in over 40 countries. Team members ("core workers") work and live alongside people in poverty ("activists"), providing practical support and a platform to amplify activists' voices on matters they value. In the UK, ATD's Family Support Programme, which covers community outreach, residential breaks and skill-sharing workshops, gives vulnerable, excluded families time, space and resources to access services and build support networks. The complementary Policy, Participation and Training projects support activists to advocate on policy and political issues. Through one such project, the Social Worker Training Programme, activists with experience of child-protection interventions deliver poverty-awareness modules to social work students and practitioners at partner universities, and debate and develop recommendations for child protection reform alongside social workers and academics.

This article includes the voices of activists cited in previous publications emerging from a workshop series linked to the Social Worker Training Programme. Ethical approval for those workshops was obtained through the Royal Holloway University of London process. In addition, Activists(a-d) were interviewed specifically for this article, and Activist(e) contributed at a roundtable discussion on The Roles We Play: Recognising the Contribution of People in Poverty (ATD \& Sajovic, 2014). Ethical approval was not 
separately sought for these interviews that were conducted voluntarily and collaboratively, by ATD, with long-term, active participants of their Social Worker Training Programme, explicitly for this article.

Although ATD is an NGO operating outside the strictures of social work systems, its philosophy and approach are adaptable, particularly for individual social workers' best practice. We apply learning from an English context, relevant given that Aotearoa New Zealand's reforms will construct a child protection model much closer to England's, and given parallels between the rate of children in poverty in care in England, and the prevalance of Māori children in Aotearoa New Zealand's care system. It exceeds this article's scope (and the authors' competencies) to suggest how better to weave tikanga and mātauranga Māori into social work's legislative and policy framework, or radical practice examples already operating within Te Ao Māori. We recognise this conversation's urgency, given $61 \%$ of children in care are Māori, and support the work many individuals and groups already do in this area (WalshTapiata, 2004), including those, like the Māori Women's Welfare League, who are highlighting how the reforms might impact Māori. We hope the kaupapa guiding ATD can be seen as both compatible with and complementary to the critically reflective, anti-oppressive competencies necessary to support such radical resistances in Aotearoa New Zealand.

\section{Acknowledging and addressing poverty's impact}

Advocating for families in poverty "does not say that children should not be properly protected. What it does say is that many parents would cope if problems associated with their poverty were taken seriously." (ATD, 2005, p. 5)

The "elephant in the room" has become the cliché moniker for poverty in child and family social work. Despite evidence linking material deprivation, social work interventions, and causative factors of abuse and neglect (Featherstone, 2016; Gupta, 2015; Pelton, 2015; Tobis, 2013), social work policy frequently downplays structural factors like poverty, inequality and social exclusion (ATD, 2005; Gupta, 2015). The Aotearoa New Zealand reforms are no exception (Oak, 2016; O’Brien, 2016). Since neoliberalisation in the 1980s, both income inequality and numbers of households in poverty have greatly increased, causing significant social disruption (Rashbrooke, 2013), and prompting research into the links between childhood poverty and lifelong vulnerabilities (Boston \& Chapple 2014). Yet, the Expert Panel's final report mentions poverty once, while references to poverty and other structural factors disappeared from policy documents defining the reforms' focus on "vulnerable children" (O'Brien, 2016). In an exchange in the House of Representatives, the Minister for Social Development (2016) confirmed that Oranga Tamariki would prioritise reducing child abuse and neglect, not child poverty.

Ignoring how poverty and structural factors create or compound families' difficulties inevitably emphasises individual responsibility and parental blame (Gupta, 2015; Tobis, 2013, p. XXv); if surrounding circumstances are not influential in creating these difficulties, something intrinsic to the family must be. Recently, Aotearoa New Zealand's former Minister of Police, Judith Collins MP reflected this logic, commenting that:

...it's people who don't look after their children, that's the problem... I can tell you it is not just a lack of money, it is primarily a lack of responsibility... I see a poverty of ideas, a poverty of parental responsibility, a poverty of love, a poverty of caring. (Frykberg, 2016, n.p.)

The Children Commissioner's Expert Advisory Group on Solutions to Child Poverty (CCEAG, 2012) encountered similar views regarding parental responsibility 
during nationwide consultation with New Zealanders about child poverty.

How issues are framed shapes the solutions presented and can distract from evidencebased policy (Featherstone, 2016). An ideology that blames individuals for social problems disincentivises context-dependent support programmes, encouraging control, surveillance, and targeted policing and "conceals the nature of poverty as a phenomenon that is, to a large extent, beyond individual control." (Krumer-Nevo, 2009, p. 318). Yet, Mason and Bywaters (2016) have observed that poverty and allegations of neglect are so interlinked that prioritising context-blind, policing-type investigations over supportive measures will likely prove both ineffective and financially inefficient. Aotearoa New Zealand child protection history contains instances of counterproductive policy stemming from a context-blind approach. Blaiklock et al. (2002) observe that "a lack of resources" made "inoperable" many of "the preventative and empowering aspects" of the otherwise revolutionary CYPFA, in the sense that the state "transferred responsibility to families, but not the resources required to allow families to exercise these responsibilities" (p. 50).

\section{Messages from ATD}

... within a lot of organisations people are paid to do a job and then they go home. They simply do not live the realities and live with poverty the way we do.

(ATD \& Sajovic, 2014, p. 116)

Consistently maintaining that poverty poses enormous difficulties for families, ATD highlights as unjust systems that blame families for not coping while failing to provide enabling resources (ATD, 2005). While individual social workers do not create this injustice, competently identifying signs and influence of material deprivation is integral to understanding solutions, tailoring expectations and exhibiting empathy. Practitioners should be aware that families find demands that they change, amidst an absence of material support, unjust.
Activist(b) notes that the practitionerfamily relationship requires both parties to recognise their mutual obligations, such that, "if social work hasn't done its job" to identify and remedy a family's contextual difficulties, "you can't condemn the family."

Appreciating the contours of material deprivation is key. When social workers can offer material support, successful application requires first identifying whether and where support is most needed. Otherwise, families may divert the resource elsewhere-for example, selling new school shoes to buy food-thus appearing either irrational or ungrateful (KrumerNevo, 2009). Furthermore, social workers who underappreciate the practicalities of material deprivation may expect families to achieve economically unrealistic feats, overlook parents' genuine attempts to do their utmost within financial constraints, or unjustly infer signs of "bad" parenting, neglect or a lack of love (ATD, 2005; Gupta, 2015; Gupta \& ATD, 2015). We should remember that:

...most parents genuinely want the best for their children... The best of themselves when you are struggling might not be that much; some parents can't read or write so they can't help children with homework, they can't control where they live, like a horrible block of flats, but what they can give, they try to give. (Activist(b))

While recognising poverty's material impacts is elementary, an activist explains how a truly radical service would recognise nonmaterial aspects too:

...people don't know enough about the mental, psychological and emotional toll of years of poverty and the impact that can have on you. It's almost as if people are expected to move on from that within a couple of weeks; in reality, the emotional effect lingers on and on and they need space to recover emotionally as well. (ATD \& Sajovic, 2014, p. 116) 
Poverty's profound relational and psychological aspects are increasingly recognised, particularly in research linking poverty and shame (Gupta \& ATD, 2015).

ATD has long underlined poverty's unseen aspects, striving to provide holistic support that facilitates families' aspirations, interests and desires through self-esteem-building, promoting validation, and combating social exclusion (Skelton, 2015, p. 81). For example, the NGO supports activists to recognise and share their (generally unpaid and unsung) contributions to society (ATD \& Sajovic, 2014), and to undertake public-speaking and campaigning opportunities: "ATD does offer me things I can't get anywhere else. I get the chance to meet new people, go to different places, do stuff for them and represent them. Nobody has ever asked me to do that before" (Activist(a)). This stance distinguishes "basic" and "higher" needs, observing that "people whose basic needs are not met still experience other needs, 'higher' needs, and they experience these needs in various ways and not in a uniform manner." (Krumer-

Nevo, 2005, p. 102).

Overlooking poverty's impact on families not only sidesteps addressing underlying structural issues of inequality but also obfuscates any revelation about how the system might unfairly target people in material deprivation. From an Aotearoa New Zealand perspective, Hyslop (2009) notes:

...notwithstanding the undisputed assertion that child abuse and family violence occur within all sectors of society, the clients of the contemporary child protection system are most often drawn from the ranks of the poor and marginalised. Practice in child protection social work is as much a classbased, gendered and culturally biased phenomenon as it ever was. (p. 66)

Traditionally, social work training and research on discrimination has emphasised issues of race, gender and disability, over poverty (ATD, 2005). Given the relative invisibility of how social work, poverty and oppression interact, Gupta (2015) suggests that "poverty has remained the great 'unsaid' of social work" (p. 10).

While "risk factors" coinciding with material disadvantage partially explain social services' disproportionate targeting of poor households, activists also pinpoint "povertyism": toxic societal discourses about people in poverty, including negative stereotyping and class-inflected presumptions about parenting standards in deprived circumstances (ATD, 2005, pp. 21-22). These discourses are not unique to England: Beddoe (2014) recently drew parallels between the UK and Aotearoa New Zealand in her analysis of negative media framing of people in poverty, including its permeation of welfare policy reform and approaches to child welfare. Social workers, as members of society, can be influenced by these discourses and may unconsciously deliver services in prejudiced or discriminatory ways (ATD, 2005): “with contemporary politics and attitudes being as damning as they are, we have to live with a lot of very bad attitudes that seriously affect how people are perceived and treated by those in positions of authority" (ATD \& Sajovic, 2014, p. 114).

ATD contends that silencing and excluding people in poverty perpetuates these attitudes, erasing society's opportunity to hear new, subjective norms about poverty and parenting, based on alternative social experiences. The NGO works to reverse this exclusion, recognising activists' expertise on how institutions, policy and law could better support them, and reiterating that activists' insights benefit social policy and society (Skelton, 2015, pp. 59-77). Unfortunately, endless institutional barriers obstruct this endeavour, including presumptions about the capacities and intelligence of people in poverty, or perceptions that their life experience is somehow biased (Skelton, 2016, p. 69). Accordingly, one core worker notes, "[w] e discovered that the main thing was not to give the poor the chance to make their 
voice heard, but to open our ears. It is not about empowering the poor, but about humanizing citizens and institutions" (as cited in Krumer-Nevo, 2005, p. 99).

Humanising social services institutions is an ongoing imperative. Too often in social work contexts, clients are considered merely recipients that expert professionals instruct (Krumer-Nevo, 2008). Families often recount feeling excluded from decisions about their own lives, while parents with experience of the system are rarely invited to share their insights on social work policy reform (Gupta \& ATD, 2015; Tobis, 2013). In Aotearoa NZ, commentators have noted similar concerns about family inclusion in CYF processeseven family group conferences (FGC) (Connolly, 2006; Moyle, 2015), yet the reforms further deprioritise parental participation vis-à-vis the state and professionals (Martin, 2016; Te Wharepora Hou, 2016).

In constructing the reform agenda, parental voices were largely disregarded. The Expert Panel featured no panellists with experience of CYF support, demonstrating the narrow view of expertise adopted. The final report made the welcome recommendation to boost young people's voices through Youth Advisory Panels, but proposed no similar initiative for greater parental advocacy. Perhaps, this discrepancy reflects the view that mechanisms such as FGCs give parents too much voice vis-à-vis children. However, this logic presumes that current settings effectively ensure parental participation. Yet, the few parents the Panel interviewed expressed the same sense of exclusion including feeling "powerless and helpless in the face of CYF" (6), confused, angry, defeated, desperate (51) and unable to participate (6). Ultimately, parents "felt many of the decisions made were predetermined, the process was slow and bureaucratic, and they lacked a voice" (51).

ATD's approach emphasises participatory inclusion. The NGO supports activists to share their critical analysis and reform proposals for more inclusive social work policy and practice, and aims to help child and family social workers operate more reflexively to avoid povertyist approaches (ATD, 2005; Gupta \& ATD, 2015). Recognising that social work education often addresses poverty cursorily or superficially (ATD, 2005; Krumer-Nevo, 2009), activists deliver poverty-awareness modules in universities to train social workers and for continuing professional education. These modules help students to incorporate structural analysis and critically reflective practice, while balancing managerialist elements in social work education. The activist-practitioner interaction enables mutual learning outside the charged contexts of an intervention, while activists find the experience meaningful:

I take part in [social worker training] because what I went through, I don't want other families going through the same. I want to make a difference where social workers will actually sit up and take notice of what families are saying to them and work with them instead of judging them. What I get out of that is knowing I have the confidence to actually speak to a social worker, whoever they are, and give them suggestions on the best way to go about a certain situation before they go in to see a family so there's a better working relationship between the two... (Activist(a))

Similarly, activists advocate for peer support in social work systems, whereby parents with experience of social work interventions help others navigate the system. Compared to what professionals alone can offer, peer support is intrinsically empathetic. A recent parent-led project to overhaul the New York care system offers inspirational evidence of the value peer support networks and parental expertise bring to policy and practice (Tobis, 2013). As one parent in that project stated, "I'm here to level out the playing field. I'm here to give parents a voice. They have rights too" (Tobis, 2013, p. xi). 


\section{Maximising collaborative practice}

...a tendency to talk about us, but not to us. It's part of a culture of having everything done to us; we're not part of anything. (ATD \& Sajovic, 2014, p. 116)

Control-heavy systems frequently impose processes and interventions on families rather than handing families power to shape the support they receive. In England, povertyism, individualised blame, and the devaluation of family inclusion in social work practice have legitimised a model that thrusts pre-defined change plans upon families (Featherstone et al., 2014). However, imposing solutions frustrates social work's aspiration to promote transformation through collaboration and relationships (Hyslop, 2009). The experience of constantly being "done to" disengages families, producing profoundly negative psychological effects:

My relationship with social services made me feel angry, degraded and suicidal at one point because I was being told what to do, when to do it and being treated like a child instead of like an adult. Being told to do $\mathrm{x}, \mathrm{y}$ and $\mathrm{z}$ by somebody that was younger than me, had no kids and the only experience they had got was by reading out of a textbook. (Activist(a))

Given their bureaucratising bent, the Aotearoa New Zealand reforms may well promote imposition, regulation and coercion (Hyslop, 2009; Keddell, 2014; Oak, 2016). The proliferation of Predictive Risk Modelling tools and Assessment Frameworks (Keddell, 2014; Oak, 2016), follows overseas patterns of "system-driven" managerialism, which coopts standardised, computerised processes for itemising, predicting and managing risk in monitored families (Cottam, 2011, p.138; Oak, 2016). Contemporaneously, support narrows to uniform interventions addressing pre-defined risk-indicators, rather than families' real issues (Keddell, 2014). Such systems promote "a dispassionate and disengaged form of practice" (Hyslop, 2009, p. 64), eroding possibilities for creativity, collaboration, and relationship-building between social workers and families (Oak, 2016). Mantras of efficiency, targets and outcomes, and predetermined governmental priorities and timescales, further restrict remaining opportunities to action families' priorities (Cottam, 2011; O’Brien, 2016).

ATD does not provide state social services. Consequently, core workers have considerable freedom to foreground empathy, human interaction and collaboration over processes and pre-set agendas. This flexibility permits radical practice, particularly creative, lateral and highly varied work, crafted alongside each family, responding to their lives' contingencies:

You gave us holidays at Frimhurst and you personally have been to court with us, you've come to meetings with us with social services, you visited us when we were in "prison" [the family assessment unit]. [Core worker] has supported [activist's wife] with her confidence, getting her out of the house when she was having her panic attacks, taken her over the Millennium Bridge while it was rocking, taken her to McDonalds. You've supported our son through the loss of his brothers, you still support him and take him out places so that when he feels he can't talk to us he talks to you and you help him try to find a way to come out with it to us. (Activist(c))

Collaborating with families requires the willingness and capability to take seriously their wishes and implement them. Activists attest to ATD's ability to listen and respond: "Everything we want, you are there for... If I ask you to come some place with me, you come. And that's what I appreciate." (Activist(c)). One mother recounted an early experience with the NGO; a core worker asked her how he could help:

I told them I just wanted a whole day on my own. I had not had a whole day 
without my children or without people knocking on my door or giving me grief for so long. And they did. They took the kids out for a day. I was gobsmacked. (Activist(b))

Essentially, this approach gives families decision-making control, rather than prising it away, recognising that freedom to compose initiatives for one's own life is "the key to transformation" (Cottam, 2011, p. 139). To some degree, such flexibility can be integrated into social workers' best practice. However, committing to advancing a family's requests can elude practitioners because working beyond institutional biases-particularly reluctance to relinquish control in risk-averse situations-requires extra effort, or may be practically limited by solutions at social workers' disposal (Krumer-Nevo, 2008).

Furthermore, certain ideologies underlying reforms in Aotearoa New Zealand may vitiate willingness to hand families greater autonomy, particularly the "social investment" and "early intervention" approaches, which promote early investment in "high risk" families to foster optimal long-term social outcomes (Expert Panel, 2015, p. 10). Commentators have observed an unspoken imperative underlying such ideologies, namely the neutralisation of social problems posed by "troubled" families, so identified by "risk factors" that happen to correspond with characteristics of multiple deprivation (O'Brien, 2016; Featherstone et al., 2014). This rhetorical process implicitly marks vulnerable families as "dangerous," and permits potential justification of coercive practice by reference to the greater social good. Activist(b) notes how such logic can pervert the role of social services:

...society is expecting these structures to be police forces and not support networks. Society has expected social workers to protect children but now they're expecting them to protect society from us. It's like the poor, the disadvantaged and the ones that struggle have somehow become a danger to society... I don't think social workers and teachers and doctors and nurses should have that in mind when they approach someone who is vulnerable.

Evidently, how social workers and policymakers treat and internally construct people receiving services affects the service delivered (Featherstone et al., 2014; Keddell, 2014). Regardless of the ideological environment, practitioners can control their perception of those with whom they work. ATD demonstrates, practically, how to avoid pathologising people in poverty. Guided by the conviction that all people are equal, core workers foreground acceptance, nonjudgement and strengths-based principles, freeing activists to take ownership on their own terms (Skelton, 2016, p. 117). Core workers realise this through not seeking to change or fix who activists are (KrumerNevo, 2009):

I was being accepted rather than changed. I wasn't being changed to fit what someone else thought I should be; I was changing because I was being helped to realise that I needed to. It was my choice to change; not theirs. (Activist(b))

This acceptance entails a willingness to meet activists where they are:

...with ATD you can go back and you don't feel like a failure, you don't feel like you've let people down; you know that you'll be accepted... I've never had ATD say to me, “Oh, you were doing so well..." I've had social workers say it, I've had teachers say it, I've had a tutor at university say it, but I've never had ATD say it. They say, "I'm glad you told me; let's see where we're at." That's very different. It's acceptance; not acceptance that you're a failure but acceptance that people do take backward steps and may need support again to move forward again. (Activist(b)) 
Lack of judgement is integral to activists' relationship with core workers and their willingness to engage with ATD:

You know our situation, you know how much we mucked up when we first got involved with social services with our kids and everything else but you've been on that journey with us. There are people out there that, as soon as they find out you've got social services involved, they don't want to know and they will judge you. You guys don't judge. (Activist(c))

Similarly, in an Aotearoa New Zealand study, social service recipients recounting positive experiences with practitioners highlighted non-judgemental approaches (Keddell, 2011). Such research demonstrates that practitioners can and do integrate nonjudgemental service provision into their best practice, and when they do, service-users notice and appreciate it, suggesting this should be encouraged and fostered.

Finally, ATD's practice is inherently strengths-based, recognising and emphasising the capacities and potential residing in families, espousing a faith in what people can be, but also in what they contribute already (ATD \& Sajovic, 2014; Skelton, 2015, p. 71). Krumer-Nevo (2009) describes how ATD's core workers:

...behave in a respectful, humane way in circumstances that for other members of society, including professional social workers would require special efforts. In their encounters with marginalized members of society, considered in most cases and by most people to be "failures", members of the Fourth World recognize their powers and their capabilities that are worthy of respect and appreciation, and they focus precisely on those. This is not always simple... But Fourth World volunteers wait patiently until something remarkable emerges, and then they concentrate on relating to this trait [thus enhancing] its presence. (pp. 311-312)
ATD's conviction that everyone has something to offer underpins its programmes, including its Skill-Sharing Workshops and Access to Volunteering, where activists volunteer in the community garden, the maintenance and refurbishment of the buildings, or the office (ATD, 2016). Activists get the chance to develop and share skills they have already. By tapping into people's strengths, the projects build confidence:

...it wasn't just about skill sharing. It was [core worker] showing me how to do things or taking some of my skills on board and letting me do things and, through that, it helped me get the confidence to get off my big, fat backside and get a job ... when you've been out of work a long time, it does help you get job-ready because you're doing things ... you're doing physical things and bringing all those skills you've learned in the past back to life. (Activist(c))

Gupta (2015) and others have advocated a capability-style approach for social work (Cottam, 2011; Featherstone et al., 2014). Indeed, strengths-based practice resonates with social work's emancipatory aspirations. However, Cottam (2011) argues that recognising families' strengths remains a "radical departure" (p. 140) for most social service systems that operate with deficitbased approaches and "the dead weight of expectation that [families] can't change" (p. 138). These expectations are corrosive: “being judged as someone who's done something wrong and 'you can never change so we don't want to know you' is... a terrible situation" (Activist(e)). Accordingly, ATD's approach stands out:

The big difference is that within [ATD], people believe in you and trust you. With social work, there's already a feeling that you've already messed things up and the only potential you have is to mess things up even more. So the emphasis is not on you giving the best of yourself but on preventing you giving the worst. (Activist(b)) 


\section{Relational approaches}

"I made friends and friends that have lasted years. When you have been very isolated for a long while and you make genuine friends, that's precious." (Activist(b))

Constructing and bolstering relationships underpins ATD's model (ATD, 2009), reflecting a "relational welfare" approach that eschews the isolating, "transactional" approach of neoliberal social services (Cottam, 2011, p. 136) to promote meaningful relationships within families and communities, and between social workers and families (Cottam, 2011; Featherstone et al., 2014).

ATD fosters trusting relationships between core workers and activists that many commentators would identify as integral to effective social work (Cottam, 2011; Featherstone et al, 2014; Keddell, 2014; Oak, 2016):

With ATD, I find that I can trust you lot. Other places where I have gone in the past, there hasn't been that trust there. Trust means I wouldn't be left there on my own to cope with difficult questions; if I was getting stuck with anything there would be somebody there that I know or could trust to help me or give me advice... (Activist(a))

Core workers can form trusting relationships because ATD's radical approach to working in solidarity with activists eschews hierarchies and power imbalances (KrumerNevo, 2009). Social workers represent the state, thus overcoming such obstacles is challenging (Healy, 2001). However, genuine faith in families, willingness to implement their wishes, and strengths-based practice can level playing fields. Furthermore, the fact that social workers carry the force of the state can be a strong suit; on the side of families, they can achieve more than representatives from NGOs like ATD could hope to offer. However, how such power is marshalled is important. Policing-style approaches reinforce power imbalances, impeding trust between families and social workers (Gupta et al., 2016). In England, the urgency underlying risk-averse, early-intervention rescue models has truncated the time needed for trusting relationships, featuring instead "an unforgiving approach to time and to parents-improve quickly or within the set time limits." (Featherstone et al., 2014, p. 1739).

Recognising that such controlling approaches are ineffective, ATD follows non-linear, long-term paths to progress, operating on families' timescales:

When you are accessing support from social services you are expected to fit certain criteria, make certain changes and then go away as if everything is fine and hunky dory. ATD understands that it has taken many years for people to get to where they're at. You can make changes short-term but your long-term habits will creep back and back and back. ATD knows that it will take time... (Activist(b))

Admittedly, ATD's freedom, as an NGO, to work this way is not applicable wholesale to social workers. Nevertheless, analysing some of its relationship-building work does highlight weak points in time-pressured, risk-averse models, awareness of which might enable social workers consciously to avoid or minimise them.

For example, core workers often find themselves filling gaps social workers leave behind, including unaddressed issues that families consider important, which arguably fall within social workers' purview, such as budget management, rent arrears, eviction, child benefit claims and other benefit assessments (ATD, 2016). Core workers also frequently help families do things that social workers have requested but not supported them to achieve. Activist(c) recounts how social services required he take weeks off work to complete parenting assessments, without helping to arrange financial assistance: "You 
helped me get my benefits sorted out; social services did nothing when it came to that. All [they] gave me was a letter but you helped me get it sorted out." These experiences beg the question of what happens to families without additional assistance beyond social services, reinforcing the need for practitioners to contextualise targeted interventions within the totality of a family's life, to avoid gaps or unintended consequences.

The long-term ramifications of time-poor models create self-reinforcing spirals that accelerate relationship breakdown. With insufficient time to build relationships and understanding, social workers and families often inhabit separate universes. Miscommunication is common due to unclear articulation of expectations, professional jargon rendering explanations of processes and procedures unintelligible, or misinterpretation of parents' emotions, such as defensiveness or anger (Gupta \& ATD, 2015; Gupta et al., 2016). Through their relationships with families, core workers frequently work to "bridge the gap" between social workers and families (ATD, 2012), "translating" what professionals say and diffusing tensions:

Having someone with a brain come to a meeting with us and explaining what social services mean if we are uptight about it helps. It means I don't lose my temper and just walk out of meetings. It's just having a neutral person there who sees it from [both] point[s] of view ... someone who understands how social services work, someone that realises if you say it that way, you ain't getting nowhere but if you're more diplomatic you might get somewhere else. (Activist(d))

Ideally, communication between social workers and families would not require translating. Practitioners could consider tools and techniques that organisations like ATD apply when acting as intermediaries. For example, where more time cannot be dedicated to families, changes to the delivery of information can still vitiate communication (and therefore, relationship) breakdowns, including avoiding jargon, employing parent advocates, and encouraging families to express themselves and their desires to ensure mutual understanding and empathy (Gupta \& ATD, 2015).

ATD also strives to bolster family relationships. Activists maintain that the disproportionate removal of children from low-income families due to neglect violates the right to family life, destroying identities, histories and connections between parent and child, siblings and wider kinship networks (Gupta et al., 2016; Featherstone et al., 2013; Skelton, 2015, p. 60). Like commentators such as Tobis (2013), Te Wharepou Hou (2016) and others, the NGO questions the socially constructed legitimacy of responding to allegations of neglect by removing children from their whānau. On this front, the Aotearoa New Zealand reforms are potentially regressive, including the VCA's "subsequent children" provisions, and vagueness surrounding whether early intervention translates into early provision of support, or a fast-tracking of draconian measures. Furthermore, the introduction of the paramountcy principle and the focus on "vulnerable children", suggest movement towards child-centred models (Martin, 2016), which can artificially sever children and their well-being from their relational context within families, pitting parents against children and disincentivising family support approaches vis-à-vis child-rescue initiatives (Featherstone et al., 2014; Gupta, 2015).

ATD refuses to view children in isolation from their familial relationships, instead striving to strengthen those relationships by giving families opportunities to enjoy each other's company outside the stresses of their home environment (ATD, 2016). For example, the "Getting Away From It" programme organises residential breaks for families at Frimhurst Family House, a country home in Surrey. One parent described how the week away "gives us a recharge ... As parents and as a couple, it gives me and my husband more time to talk 
to each other and more time to spend with our son." (ATD, 2016, n.p.) A 12-year-old girl echoes these sentiments: "This stay had a good impact on my family because we never spend any time together. We had fun doing activities together" (ATD, 2016, n.p.).

Alongside core worker/activist relationships and familial bonds, ATD fosters community by "[c]reating the conditions for families to form new friendships, build[ing] new connections and see[ing] themselves within a broader network of support" (ATD, 2016, n.p.). Through its programmes and campaigns, activists enter a crossgenerational network built upon shared experiences and group projects:

When you get ATD support, you're in a relationship with a whole bunch of other people. It can be aggravating and it can drive you mad. But it's always there and it lasts... We're like an extended family, we have our arguments and quarrels ... We're a community. I've lived on my estate for nearly twenty-two years, I don't have a solid community around me. I travel all the way across London ... to the headquarters of ATD Fourth World and am surrounded by a community... (Activist(b))

Relationships between activists are as important as those with core workers. Sharing in the giving and receiving of support means that no one is solely a "recipient" of services:

I got the opportunity to do something not just for myself: help with the mailout, answer the phones, meet-andgreet, make tea, go with core workers to visit families and encourage them to come to Frimhurst, to be part of things. (Activist(b))

Furthermore, the understanding born of shared experience is key:

You could talk to anyone because many of them were going through the same things as you have ... When you've gone through things together you become very, very close, when you've lost your children and other people have lost their children too ... In ATD I found the people around me had actually uplifted me because they were able to say, "I've been through that too." (Activist(e))

\section{Impacts for practitioners in Aotearoa New Zealand}

Social workers cannot absorb uncritically all practice approaches adopted by radical social movements operating external to state-provided social work systems. Indeed, pretending one can deliver services like an NGO might create false promises or lead families to misconstrue their relationship with their social worker. Such relationships inevitably include elements of control largely absent between activists and core workers (Healy, 2001). Additionally, inflexible, top-down systems constrain social workers. As Activist(b) notes:

There is a lot that social services could take from the way ATD works with families ... But, as much as I have great faith in the Social Worker Training Programme and altering how social workers think about their practice is great, unless you can alter the culture within which they have to work then I'm not sure that social work will benefit. Social workers will benefit and families will benefit and families training social workers will make a difference but the best social workers in the world when they are working in an environment that is destructive and doesn't allow them to be a good social worker...

Nevertheless, when tensions arise between social workers' aspirations and systemic ideologies, individual practitioners often activate personal mechanisms to navigate and negotiate the system, and resolve tensions to uphold social work aspirations. 
Indeed, activists are not universally negative about social workers and do relate positive experiences. These reflections often involve examples of social workers displaying respect and trust for the family, by listening and finding ways to implement their wishes (Gupta \& ATD, 2015, pp. 136-137). This suggests that considerable difference is possible through practitioners supplementing their own best practice approaches with elements that reflect ATD's philosophical fundamentals, namely respect for people in poverty and a willingness to follow families' guidance.

Furthermore, though local reforms seem to shift child protection policies towards control, Healy (2001, n.p.) notes, that "crises for critical social work also present opportunities." The outcome of these reforms is no forgone conclusion. The policies contain significant elements that could have divergent effects depending on their frontline implementation, particularly directives such as "social investment" and "early intervention." While the contemporaneous logic of control, time restrictions, and "early intervention" can create a "perfect storm" of rapid and draconian interventions (Featherstone et al., 2014, p. 1736), early intervention investment approaches could equally suggest greater time with families (because interventions precede crises) and a focus on relationship-building and material support to prevent social ills stemming from social exclusion and deprivation. Furthermore, whether interventions and investments are strengths-based or deficit-based, or foreground material deprivation or character defects, may be key determiners for whether the reforms operate progressively or oppressively. Practitioners might consider using this moment of transition to nudge implementation of malleable aspects of the reforms in emancipatory rather than oppressive directions.

Finally, embedded in ATD's model is the validation of activists' lived experiences of poverty and inequality through advocacy for social transformation. Accordingly, we urge social workers not to shy from speaking out against reforms that could make core social justice tenets of their profession nigh impossible. Furthermore, we note that ATD is indebted to the intelligence, sensitivity, and resilience of activists, who contribute so much time and energy to the shared project of eradicating poverty. As Skelton (2016) explains, "[f]ar from being 'beneficiaries,' people in poverty drive ATD Fourth World forward" (p. 111). The social work profession could be radically transformed by mainstreaming a similar recognition that the people with whom they work are social workers' greatest allies to achieving the profession's aspiration of a flourishing society.

\section{Conclusion}

Rapid, profound legislative and social policy change in Aotearoa New Zealand indicates a shift towards policies promoting social control and deprioritising collaborative practice. Nevertheless, ATD's work in England demonstrates that families can be supported to navigate neoliberal, risk-averse social work systems, and that mitigating negative aspects of such systems is possible. In this endeavour, ATD's practice and philosophy offers techniques for adapting to harsh environments, overcoming attitudes that unnecessarily hamper caring practice, and the inspiration to speak out with those who suffer. We contend that much of these techniques can be integrated (adapted, as necessary) into individual social workers' best practice and that a bottom-up institutional culture shift offers a tangible means of preserving and enhancing the profession's radical aspirations within the current (and future) social work system. Ultimately, much rests on a concerted effort to acknowledge the complex structural factors that shape people's lives, the ability to accept all people as equal in dignity and humanity, and the willingness to listen to what they have to say. 


\section{References}

ATD Fourth World. (2005). Getting the right trainers, London, UK: Author.

ATD Fourth World. (2009). Annual review. Available on request from atd@ atd-uk.org

ATD Fourth World. (2012). Annual review. Retrieved from http://www.atd-fourthworld.org/wp-content/uploads/ sites/5/2015/07/2012-annual-review.pdf

ATD Fourth World. (2016). Annual review. Available on request from atd@ atd-uk.org

ATD Fourth World, \& Sajovic, E. (2014). The roles we play: Recognising the contribution of people in poverty. London, UK: Author.

Beddoe, L. (2014). Feral families, troubled families: The spectre of the underclass in New Zealand. New Zealand Sociology, 29(3), 51-68.

Blaiklock, A., Kiro, C., Belgrave, M, Low, W., Davenport, E., \& Hassall, I. (2002). When the invisible hand rocks the cradle: New Zealand children in a time of change. (UNICEF, Innocenti Working Paper No. 93).

Boston, J., \& Chapple, S. (2014). Child poverty in New Zealand. Wellington, NZ: Bridget Williams Books.

Children's Commissioner's Expert Advisory Group on Solutions to Child Poverty (2012). Solutions to child poverty in New Zealand: Evidence for action. Retrieved from http://www.occ.org.nz/assets/Uploads/EAG/Finalreport/Final-report-Solutions-to-child-poverty-evidencefor-action.pdf

Connolly, M. (2006). Fifteen years of family group conferencing: Coordinators talk about their experiences in Aotearoa New Zealand. British Journal of Social Work, 36(4), 523-540.

Cottam, H. (2011). Relational welfare. Soundings, 48, 134-144.

Expert Panel on Modernising Child Youth and Family. (2015). Final report: Investing in New Zealand's children and their families. Retrieved from https://www.msd.govt.nz/ documents/about-msd-and-our-work/work-programmes/ investing-in-children/investing-in-children-report.pdf

Featherstone, B. (2016). Telling different stories about poverty, inequality, child abuse and neglect. Families, Relationships and Societies, 5(1), 147-153. doi:10.1332/ 204674316X14540714620085

Featherstone, B., Morris, K., \& White, S. (2013). Moving from the individual to the relational: Child protection re-imagined. In Participle (Ed.), The relational welfare blog: Collection of posts (pp. 18-20). Retrieved from http://www.participle.net/our-vision

Featherstone, B., Morris, K., \& White, S. (2014). A marriage made in hell: Early intervention meets child protection. British Journal of Social Work, 44, 1735-1749. doi:10.1093/bjsw/bct052

Frykberg, E. (2016, October 12). "I see... a poverty of parental responsibility". Radio New Zealand. Retrieved from http://www.radionz.co.nz/news/political/315489/ 'i-see-a-poverty-of-parental-responsibility'

Gupta, A. (2015). Learning from others: An autoethnographic exploration of children and families social work, poverty and the capability approach. Qualitative Social Work. [Advance online publication]. doi:10.1177/1473325015620946

Gupta, A., \& ATD Fourth World. (2015). Poverty and shame-Messages for social work. Critical and Radical
Social Work, 3(1), 131-139. doi:10.1332/20498601 $5 \times 14212365837689$

Gupta, A., Blumhardt H., \& ATD Fourth World. (2016). Giving poverty a voice: families' experiences of social work practice in a risk-averse child protection system. Families, Relationships and Societies, 5(1), 163-172. doi:10.1332/204674316X14540714620166

Healy, K. (2001). Reinventing critical social work: Challenges from practice, context and postmodernism. Critical Social Work, 2(1).

Hyslop, I. (2009). Child protection policy and practice: A relationship lost in translation. Social Policy Journal of New Zealand, 34, 61-72.

Keddell, E. (2011). Reasoning processes in child protection decision making: Negotiating moral minefields and risky relationships. British Journal of Social Work, 41 1251-1270. doi:10.1093/bjsw/bcr012

Keddell, E. (2014). The ethics of predictive risk modelling in the Aotearoa/New Zealand child welfare context: Child abuse prevention or neo-liberal tool? Critical Social Policy, 35(1), 69-88. doi:10.1177/ 0261018314543224

Krumer-Nevo, M. (2005). Listening to "life knowledge": A new research direction in poverty studies. International Journal of Social Welfare, 14, 99-106.

Krumer-Nevo, M. (2008). From noise to voice: How social work can benefit from the knowledge of people living in poverty. International Social Work, 51(4), 556-565. doi:10.1177/0020872808090248

Krumer-Nevo, M. (2009). Four scenes and an epilogue: Autoethnography of a critical social work agenda regarding poverty. Qualitative Social Work, 8(3), 305-320. doi:10.1177/1473325009337839

Martin, S. (2016). Shifting power relations in New Zealand child welfare policy: The process and implications of the 2014 amendment to $\mathrm{s} 13$ of the CYP\&tF Act. Aotearoa New Zealand Social Work, 28(2), 40-50.

Mason, W., \& Bywaters, P. (2016). Poverty, child abuse and neglect: patterns of cost and spending. Families, Relationships and Societies, 5(1), 155-161. doi:10.1332/ 204674316X14540714620201

Minister for Social Development (2016, September 21). 717 NZPD (Hansard). Retrieved from https://www. parliament.nz/en/pb/hansard-debates/rhr/combined/ HansD_20160921_20160921

Moyle, P. (2015). Mãori-lived-experiences of the Family Group Conference: A selection of findings. Unpublished manuscript. Retrieved from https://www.academia. edu/10578356/M\%C4\%81ori-Lived-Experiences_of_the Family_Group_Conference_A_selection_of_findings.

Munby, J. (2016). Care cases-The looming crisis (14 ${ }^{\text {th }}$ View from the President of the Family Division). Retrieved from https://www.judiciary.gov.uk/wp-content/uploads/2014/08/ pfd-view-15-care-cases-looming-crisis.pdf.

Oak, E. (2016). A minority report for social work? The predictive risk model (PRM) and the Tuituia assessment framework in addressing the needs of New Zealand's vulnerable children. British Journal of Social Work, 46, 1208-1223. doi:10.1093/bjsw/bcv028

O'Brien, M. (2016). The triplets: Investment in outcomes for the vulnerable-Reshaping social services for (some) New Zealand children. Aotearoa New Zealand Social Work, 28(2), 9-21. 
Pelton, L. (2015). The continuing role of material factors in child maltreatment and placement. Child Abuse and Neglect, 41, 30-39.

Rashbrooke, M. (2013). Why inequality matters. In M. Rashbrooke (Ed.), Inequality: A New Zealand crisis (pp. 1-19). Wellington, NZ: Bridget Williams Books.

Skelton, D. F. (2015). Artisans of peace: Overcoming poverty, Vol. 1: A people-centered movement. Pierrelaye, France: ATD Fourth World.

Skelton, D. F. (2016). Artisans of peace: Overcoming poverty, Vol. 2: Defending human rights. Pierrelaye, France: ATD Fourth World.

Te Wharepora Hou: Māori Women's Network. (2016, October 9). \#Hands Off Our Tamariki: An Open Letter [Web log post]. Retrieved from https://tewhareporahou.wordpress. com/2016/10/09/hands-off-our-tamariki-an-open-letter/

Tobis, D. (2013). From pariahs to partners: How parents and their allies changed New York City's child welfare system. New York, NY: Oxford University Press.

Tolley, A. (2015, April 1). Independent expert panel to lead major CYF overhaul. [Press release]. Retrieved from https://www.beehive.govt.nz/release/independent-expertpanel-lead-major-cyf-overhaul

Walsh-Tapiata, W. (2004). The past the present and the future: The New Zealand indigenous experience of social work. Social Work Review, 16(4), 30-37.

Warner, J. (2015). The emotional politics of social work and child protection. Bristol, UK: Policy Press.

\section{End Notes}

The government established the Panel to review Aotearoa NZ's care and protection system, following criticism of CYF's performance protecting vulnerable children (Tolley, 2015). 